\title{
Cancer/stroma interplay via cyclooxygenase-2 and indoleamine 2,3-dioxygenase promotes breast cancer progression
}

\author{
Jing-Yi Chen ${ }^{1}$, Chien-Feng Li ${ }^{2}$, Cheng-Chin Kuo ${ }^{3}$, Kelvin K Tsai ${ }^{1}$, Ming-Feng Hou ${ }^{4,5,6}$ and Wen-Chun Hung ${ }^{1,6,7^{*}}$
}

\begin{abstract}
Introduction: Expression of indoleamine 2,3-dioxygenase (IDO) in primary breast cancer increases tumor growth and metastasis. However, the clinical significance of stromal IDO and the regulation of stromal IDO are unclear.

Methods: Metabolomics and enzyme-linked immunosorbent assay (ELISA) were used to study the effect of cyclooxygenase-2 (COX-2)-overexpressing breast cancer cells on IDO expression in co-cultured human breast fibroblasts. Biochemical inhibitors and short-hairpin RNA (shRNA) were used to clarify how prostaglandin $E_{2}$ $\left(\mathrm{PGE}_{2}\right)$ upregulates IDO expression. Associations of stromal IDO with clinicopathologic parameters were tested in tumor specimens. An orthotopic animal model was used to examine the effect of COX-2 and IDO inhibitors on tumor growth.
\end{abstract}

Results: Kynurenine, the metabolite generated by IDO, increases in the supernatant of fibroblasts co-cultured with COX-2-overexpressing breast cancer cells. PGE $_{2}$ released by cancer cells upregulates IDO expression in fibroblasts through an EP4/signal transducer and activator of transcription 3 (STAT3)-dependent pathway. Conversely, fibroblast-secreted kynurenine promotes the formation of the E-cadherin/Aryl hydrocarbon receptor (AhR)/S-phase kinase-associated protein 2 (Skp2) complex, resulting in degradation of E-cadherin to increase breast cancer invasiveness. The enhancement of motility of breast cancer cells induced by co-culture with fibroblasts is suppressed by the IDO inhibitor 1-methyl-tryptophan. Pathological analysis demonstrates that upregulation of stromal IDO is a poor prognosis factor and is associated with of COX-2 overexpression. Co-expression of cancer COX-2 and stromal IDO predicts a worse disease-free and metastasis-free survival. Finally, COX-2 and IDO inhibitors inhibit tumor growth in vivo.

Conclusion: Integration of metabolomics and molecular and pathological approaches reveals the interplay between cancer and stroma via COX-2, and IDO promotes tumor progression and predicts poor patient survival.

\section{Background}

Chronic inflammation is strongly associated with the development of cancer [1-3]. One of the crucial mediators of inflammatory reaction is cyclooxygenase (COX). The COX family of enzymes comprises two members (COX-1 and COX-2) and is the main controller of eicosanoid biosynthesis. Studies of human breast tumor tissues demonstrate that upregulation of COX-2 has been detected in

\footnotetext{
* Correspondence: hung1228@nhri.org.tw

${ }^{1}$ National Institute of Cancer Research, National Health Research Institutes,

No. 367, Shengli Road, Tainan 704, Taiwan

${ }^{6}$ Cancer Center, Kaohsiung Medical University Hospital, Kaohsiung 807,

Taiwan

Full list of author information is available at the end of the article
}

approximately $40 \%$ of human breast tumor tissues, as well as preinvasive ductal carcinoma in situ lesions [4]. Elevated expression of COX-2 is associated with large tumor size, advanced histologic grade, axillary node metastasis, and unfavorable disease-free survival $[4,5]$. In addition, COX-2 expression also links with increased tumor angiogenesis [6]. Epidemiologic investigations suggest that use of nonsteroidal antiinflammatory drugs or selective COX-2 inhibitors reduces breast cancer risk $[7,8]$.

Results of animal study also support an oncogenic role of COX-2. Transgenic COX-2 overexpression induces mammary tumor formation in mice [9]. This tumorigenic transformation is highly dependent on $\mathrm{PGE}_{2}$ production and angiogenic switch. In addition, $\mathrm{HER}-2 / \mathrm{Neu}$ 
oncogene-induced mammary tumorigenesis and angiogenesis are dramatically attenuated in COX-2 knockout mice, suggesting a key role of COX-2 in breast cancer [10]. Recent studies also show that COX-2 inhibitors exhibit antitumor and antiangiogenic activities in vivo and exhibit chemopreventive effects against mammary carcinogenesis induced by 7,12-dimethyl-benz(a)anthracene in rats [11]. All of the results suggest that COX-2 is involved in multiple steps of breast carcinogenesis and is a potential target for cancer prevention and therapy.

Interplay between breast cancer cells and cancerassociated fibroblasts (CAFs), the most abundant and active stromal cells, is crucial for tumor growth, progression, angiogenesis, and therapeutic resistance [12]. Cancer cells release a number of factors to enhance the production of cytokines, chemokines, and matrix metalloproteinases (MMPs) from CAFs, which in turn facilitate cancer cell proliferation, migration, and invasion. Previous study demonstrated that stromal fibroblasts present in invasive breast carcinomas can secrete large amounts of stromal cell-derived factor 1 (SDF-1) to enhance tumor growth and angiogenesis [13]. Co-injection of breast cancer cells and fibroblasts also promotes the progression of ductal carcinoma in situ to invasive breast carcinoma by stimulating chemokine (C-X-C motif) ligand 14 (CXCL14) and chemokine (C-X-C motif) ligand 12 (CXCL12) production [14]. However, most studies addressing the crosstalk between cancer and stromal cells focus on protein factors like cytokines and chemokines. Whether other small molecules such as lipids or metabolites participate in cancer-stromal cell interaction is largely unknown.

The tumor-promoting role of CAFs via upregulation of COX-2 in ductal carcinoma in situ of the breast was first demonstrated by $\mathrm{Hu}$ et al. [15]. The authors showed that co-culture with fibroblasts increases COX-2 expression in breast cancer cells and subsequently induces MMP-9 and MMP-14 in these cells to promote invasion. They also elucidated the underlying mechanism by demonstrating that inhibition of nuclear factor kappa-light-chain-enhancer of activated B cells (NF- $\mathrm{kB}$ ) and COX-2 activity reduces the invasion-promoting effect of fibroblasts. These data suggest that fibroblasts secrete some factors to activate NF- $\mathrm{BB}$ mediated transcription of COX-2 in breast cancer cells to enhance tumor progression.

However, several issues remain elusive. First, does $\mathrm{PGE}_{2}$ generated by COX-2-expressing cancer cells also affect gene expression or behavior of stromal fibroblasts? Second, do CAFs secrete small molecules (other than proteins or peptides) to regulate cancer cell invasion? Finally, can the importance of cancer-stroma interaction in cancer progression be validated in clinical samples?

In this study, we address these questions and try to clarify the underlying mechanism.

\section{Methods}

\section{Cell culture}

Human breast cancer cell lines MCF-7 and MDA-MB-231 were purchased from the Bioresource Collection and Research Center (BCRC) and ATCC. Immortalized human breast fibroblasts, RMF-EG [16], were kindly provided by Dr. Charlotte Kuperwasser (Tufts University, Boston, MA, USA). These cells were cultured in DMEM/F12 containing $10 \%$ fetal bovine serum (FBS). Other experimental materials and procedures are provided in Additional file 1.

\section{Establishment of inducible COX-2-expression MCF-7 cell line}

To establish an inducible COX-2-expression cell line, MCF-7 cells $\left(1 \times 10^{6}\right)$ were resuspended in buffer $R$ containing $2 \mu \mathrm{g}$ pCMV-Tet3G plasmid. Transfection was performed by using Neon microporation transfection system at room temperature with 1,250 V, 20 milliseconds, and two pulses. After 48 hours, the cells were selected with $1 \mathrm{mg} / \mathrm{ml} \mathrm{G} 418$ for 2 weeks.

For the delivery of the second plasmid, pCMV-Tet3G stably transfected cells $\left(1 \times 10^{6}\right)$ were resuspended in buffer $\mathrm{R}$ containing $2 \mu \mathrm{g}$ of pTRE-mCherry-COX-2 plasmid. Transfection was performed by using Neon microporation transfection system at room temperature with $1,250 \mathrm{~V}, 20$ milliseconds, and two pulses. After 48 hours, the cells were subjected to selection with $100 \mu \mathrm{g} / \mathrm{ml}$ hygromycin B. The stable cell line harbors both pCMV-Tet3G and pTREmCherry-COX-2 plasmid was used for induction experiment. The cells were maintained at $37^{\circ} \mathrm{C}$ in a $5 \% \mathrm{CO}_{2}$-humidified atmosphere and were incubated with doxycycline to induce COX-2 expression before co-culture assay.

\section{Co-culture assay}

In the co-culture system, $1 \times 10^{5}$ RMF-EG cells were grown in the bottom of a six-well plate in DMEM/F12 with $10 \% \mathrm{FBS}$, and $1 \times 10^{6}$ breast cancer cells were seeded on the $0.4-\mu \mathrm{m}$ polyester membrane of a transwell insert in the same medium. MCF-7 cells were treated with or without doxycycline $(1 \mu \mathrm{g} / \mathrm{ml})$ for 72 hours. The conditioned medium, breast cancer cells, and RMF-EG cells were harvested for metabolomics and Western blotting analysis.

\section{Metabolite profiling}

The proteins in the conditioned medium were removed by using $3-\mathrm{kDa}$ ultracentrifugation filter devices. The metabolites in the filtered medium were extracted by using iced 50\% methanol and were subsequently dried by a speedvac. Metabolite profiles were analyzed with the Metabolomics Core of National Health Research Institutes by using a high-resolution ultraperformance liquid chromatography (UPLC) coupled online to a triple-quadrupole time-of-flight mass spectrometry system, as described previously [17]. Metabolite identity was predicted with Human Metabolome Database [18]. 


\section{RNA extraction and quantitative reverse transcription-PCR analysis}

Total RNA was isolated from cells by using an RNA extraction kit (Qiagen, Valencia, CA, USA) and $1 \mu \mathrm{g}$ of RNA was reverse-transcribed to cDNA. Target mRNAs were quantified by using real-time PCR reactions with SYBR green fluorescein, and actin served as an internal control. cDNA synthesis was performed at $95^{\circ} \mathrm{C}$ for $3 \mathrm{mi}-$ nutes, and the conditions for PCR were 28 cycles of denaturation $\left(95^{\circ} \mathrm{C} / 1\right.$ minute), annealing $\left(60^{\circ} \mathrm{C} / 1\right.$ minute) extension $\left(72^{\circ} \mathrm{C} / 1\right.$ minute), and 1 cycle of final extension $\left(72^{\circ} \mathrm{C} / 10\right.$ minutes). The primers used are tryptophan $2,3-$ dioxygenase (TDO)-forward: 5'-GGGAACTACCTGCAT TTGGA-3'; TDO-reverse: 5'-GTGCATCCGAGAAACA ACCT-3'; IDO-forward: 5'-GCGCTGTTGGAAATAG CTTC-3'; IDO-reverse: 5'-CAGGACGTCAAAGCACTG AA-3'; E-cadherin-forward: 5' -CCTGGGACTCCACCTA CAGA-3'; E-cadherin-reverse: 5' -GGATGAACACAGCG TGAGAGA-3'; actin-forward: 5' -TGTTACCAACTGGG ACGACA-3'; actin-reverse: 5' -GGGGTGTTGAAGGTCT CAAA-3'.

\section{Immunoprecipitation and Western blot analysis}

MCF-7or COX-2-overexpressing MCF-7 cells were treated with or without $100 \mu M$ kynurenine for 24 hours; the cells were harvested with an RIPA buffer $(50 \mathrm{~m} M$ Tris- $\mathrm{HCl}$, pH 7.4, $150 \mathrm{mM} \mathrm{NaCl}, 1 \% \mathrm{NP}-40,0.1 \%$ SDS, 0.5\% sodium deoxycholate, $2 \mathrm{mM}$ EDTA, and $50 \mathrm{mM} \mathrm{NaF}$ ), and cellular lysates were incubated with anti-AhR antibody overnight at $4^{\circ} \mathrm{C}$ with rotation. Immunocomplexes were pulled down by Protein-G agarose bead, washed with RIPA buffer 3 times, and eluted with a sample buffer in boiled water for 10 minutes. The eluted samples were subjected to SDS-PAGE separation, and proteins were transferred to nitrocellulose membranes. Finally, the blots were probed with anti-E-cadherin or anti-Skp2 antibody and developed with enhanced chemiluminescence reagent.

\section{Migration assay}

Migration assays were conducted in transwells with 8 - $\mu$ m-pore filter inserts. Then $1 \times 10^{4}$ MCF-7 or COX-2-overexpressing MCF-7 cells were seeded in the upper chamber. The lower chambers were filled with DMEM medium containing $1 \%$ FBS and $100 \mu M$ kynurenine. After 24 hours, the cells on the upper surface were removed by wiping with a cotton swab, and the cells that migrated to the lower surface were fixed. The cells were stained with 4',6-diamidino-2phenylindole (DAPI), and the cell number in 15 randomly selected fields was counted under a microscope $(100 \times)$. Experiments were performed independently at least 3 times.

\section{Protein ubiquitination assay}

MCF-7 cells treated with or without kynurenine were incubated with the proteasome inhibitor MG132 or the lysosome inhibitor chloroquine. The cells were harvested with a lysis buffer $(20 \mathrm{~m} M$ Tris- $\mathrm{HCl}$ at $\mathrm{pH} 7.5,150 \mathrm{~m} M$ sodium chloride, $1 \mathrm{~m} M$ calcium chloride, and 1\% Triton X-100 and protease inhibitors), and cellular lysates were incubated with an E-cadherin antibody overnight at $4^{\circ} \mathrm{C}$ with rotation. Protein- $\mathrm{G}$ beads were added to the samples and incubated for another 1 hour at $4^{\circ} \mathrm{C}$. Immunocomplexes were eluted and were subjected to SDS-PAGE separation, and proteins were transferred to nitrocellulose membranes. Finally, the blots were probed by using an anti-ubiquitin antibody to detect the ubiquitination status of E-cadherin.

\section{Immunofluorescent staining and confocal microscopy}

MCF-7 cells were treated with or without $100 \mu M$ kynurenine for 6 hours and fixed with 3.7\% formaldehyde for 15 minutes at room temperature. Cells were washed twice with PBS and permeabilized by $0.1 \%$ Triton X-100 solution for 10 minutes. After permeabilization, cells were incubated with $0.05 \%$ BSA solution to block nonspecific binding. Anti-AhR mouse monoclonal antibody (1:80) or anti-E-cadherin goat polyclonal antibody (1:250) was added and incubated at room temperature for 1 hour. After extensive washing, Alexas Fluro 594 anti-mouse IgG or Alexas Fluro 488 anti-goat IgG was added and incubated for another 1 hour. Cell nuclei were stained with DAPI solution. Finally, coverslips were washed twice with PBS and subsequently placed in mounting solution. The fluorescent image was observed under a confocal microscope.

\section{In vivo orthotopic animal study}

MCF-7 or MCF-7-COX2 $\left(8 \times 10^{6}\right)$ cells were mixed with RMF-EG $\left(6 \times 10^{6}\right)$ cells in Hanks balanced salt solution and Matrigel (BD Transduction Laboratories, San Jose, CA, USA). Cells were inoculated into the fourth mammary fat pads of 6-week-old female BALB/cAnN.CgFoxn1nu/CrlNarl mice. Before the inoculation of the cancer cell/fibroblast mixture, all mice were primed with $6 \mathrm{mg} / \mathrm{kg}$ of $17 \beta$-estradiol twice a week for 3 weeks.

After inoculation, $17 \beta$-estradiol was continuously given to mice throughout the experiments. Measurement of tumor growth was begun at 4 weeks after injection, and tumor volume was calculated by using the equation: tumor volume $=\left(\right.$ length $\times$ width $\left.^{2}\right) / 2$. After 10 weeks, mice injected with COX-2-overexpressing MCF-7 and RMF-EG produced tumors with volumes approximately $200 \mathrm{~mm}^{3}$ and were randomly divided into four groups that received vehicle (DMSO), NS-398 (10 mg/kg), L-1-methy-tryptophan $(10 \mathrm{mg} / \mathrm{kg})$, or both inhibitors 5 times per week.

Two weeks later, animals were killed, and tumors were isolated from mice. The statistical difference between experimental groups was evaluated with repeated-measures 
two-way ANOVA analysis. The animal-use protocol was approved by the Institutional Animal Care and Use Committee of National Health Research Institutes.

\section{Patients and statistical analysis}

Paraffin-embedded human breast tumor tissues were obtained from Chi-Mei Medical Center (Tainan, Taiwan) between 1998 and 2004. The slides were stained with anti-COX-2 or anti-IDO antibodies. The COX-2 and IDO stainings were interpreted by using the $\mathrm{H}$-score, defined by the following equation: $\mathrm{H}$-score $=\Sigma \mathrm{Pi}(\mathrm{i}+1)$, as previously described [19], where $\mathrm{i}$ is the intensity of the stained tumor cells ( 0 to $3+$ ), and $\mathrm{Pi}$ is the percentage of stained tumor cells with various intensities. We classified tumors with cancer cells and stromal cells showing $\mathrm{H}$-scores no less than the median of all scored cases as having high COX-2 and IDO expression, respectively.

The follow-up duration ranged from 5.4 to 143.6 months, with a mean of 87.1 months. Survival analyses for diseasespecific and metastasis-free survival were performed by using Kaplan-Meier plots and compared by using the log-rank test. The correlation between COX-2 and IDO expression with clinicopathologic parameters was examined with $\chi^{2}$ test. $P$ value $<0.05$ was considered statistically significant. This study was approved by the Research Ethics Committee of National Health Research Institutes. Written informed consent was obtained from all patients participating in this study.

\section{Results}

COX-2-overexpressing breast cancer cells upregulated IDO expression in co-cultured fibroblasts

We analyzed the metabolite profile of the supernatant of RMF-EG human breast fibroblasts co-cultured with MCF-76 or COX-2-overexpressing MCF-7 cells and found that several metabolites were increased in the supernatant of COX-2-overexpressing MCF-7/RMF-EG co-culture. A peak with the $\mathrm{m} / \mathrm{z}$ ratio of 209 was increased about twofold (Figure 1A). By using Human Metabolome Database search, a candidate metabolite was predicted to be kynurenine. UPLC/MS/MS analysis demonstrated that fragmentation of kynurenine standard yielded three peaks with $\mathrm{m} / \mathrm{z}$ ratio of 209,192 , and 146 , which is consistent with the reported data (accession: K0009019, MassBank, [20]) (Figure 1B). Significant increase of kynurenine was confirmed with an ELISA assay (Figure 1C).

The rate-limiting enzymes in the generation of kynurenine are indoleamine 2,3-dioxygenase (IDO) and tryptophan 2,3-dioxygenase (TDO). We found a 2.5-fold of increase of IDO mRNA in RMF-EG cells co-cultured with COX2-overexpressing MCF-7 cells, whereas the expression of TDO was not changed (Figure 1Di). A similar increase of IDO protein level was also found (Figure 1Dii). IDO was very low or undetectable in MCF-7- and COX-2- overexpressing MCF-7 cells, indicating that the kynurenine in the co-cultured medium was produced mainly by RMF-EG cells (Figure 1E). Co-culture of the COX2-overexpressing MDA-MB-231 cells also upregulated IDO expression in RMF-EG cells (Figure 1F). These data suggest that $\mathrm{COX}$-2-overexpressing breast cancer cells stimulate IDO expression and increase kynurenine secretion in co-cultured fibroblasts.

$\mathrm{PGE}_{2}$ transcriptionally elevated IDO expression in RMF-EG fibroblasts through the EP4/STAT3 signaling pathway We found that $\mathrm{PGE}_{2}$ increased IDO $\mathrm{mRNA}$ and protein levels in RMF-EG cells (Figure 2Ai and 2Aii). In addition, our data showed that only $\mathrm{PGE}_{2}$-alcohol (an EP4 agonist) significantly upregulated IDO expression (Figure 2B). Knockdown of EP4 abolished $\mathrm{PGE}_{2}$-induced increase of IDO in these cells (Figure 2Ci and 2Cii). By using different IDO deletion promoters, we demonstrated that $\mathrm{PGE}_{2}$ stimulated IDO transcription via the $-1,140 /-844$ region from the transcription start site (see Additional file 2: Figure S1). This region contained two potential $\gamma$-interferon-activated sites (GASs) that could be activated by different signal transducer and activator of transcription (STAT) proteins $[21,22]$. Both STAT1 and STAT3 have been implicated in the regulation of IDO expression [23,24].

We performed a ChIP assay and found that the binding of STAT3 to IDO promoter was increased in RMF-EG cells co-cultured with COX-2-overexpressing MCF-7 cells, whereas the binding of STAT1 was decreased (see Additional file 3: Figure S2). Knockdown of STAT3 abolished the increase of IDO induced by the EP4 agonist in RMF-EG cells (Figure 2D). Ectopic expression of STAT3 upregulated IDO (2.8-fold) in these cells (Figure 2E). Thus, COX-2overexpressing breast cancer cells upregulate IDO expression in fibroblasts through the $\mathrm{PGE}_{2} / \mathrm{EP} 4 / \mathrm{STAT} 3$ pathway.

\section{IDO-expressing fibroblasts enhanced the migration of} breast cancer cells through downregulation of E-cadherin We next studied the effect of kynurenine on breast cancer cells. Kynurenine did not affect the proliferation of MCF-7 cells (Figure 3A). However, kynurenine significantly increased the motility of MCF-7 and COX-2overexpressing MCF-7 cells (Figure 3B). The conditioned medium of RMF-EG fibroblasts preincubated with COX-2overexpressing MCF-7 cells also increased the motility of MCF-7 cells (Figure 3C). We used 1-methyl-L-tryptophan to inhibit IDO activity in RMF-EG fibroblasts induced by co-culture with COX2-overexpressing MCF-7 cells and found that the stimulatory effect on cell motility was blocked (Figure 3C). These data suggested that kynurenine released by IDO-expressing fibroblasts enhanced the migration of breast cancer cells.

We investigated the expression of epithelial-to-mesenchymal markers in kynurenine-treated breast cancer cells and found 


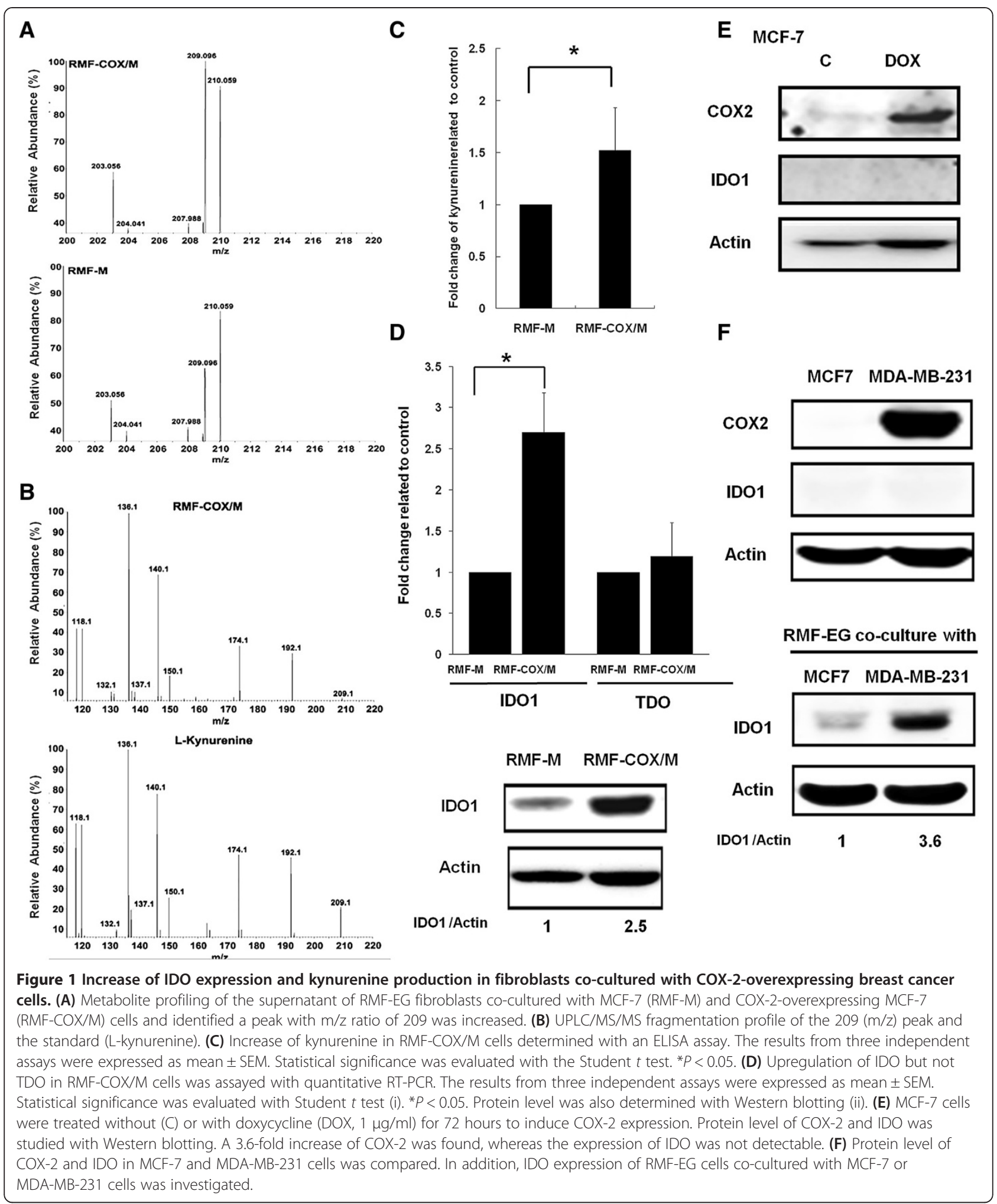

that E-cadherin was reduced in a time-dependent manner (Figure 3Di). E-cadherin began to decrease around 8 hours after addition of kynurenine, and a $70 \%$ of reduction was found at 24 hours. However, its mRNA did not decrease substantially (Figure 3Dii). We found that kynurenine induced degradation of E-cadherin protein via a 


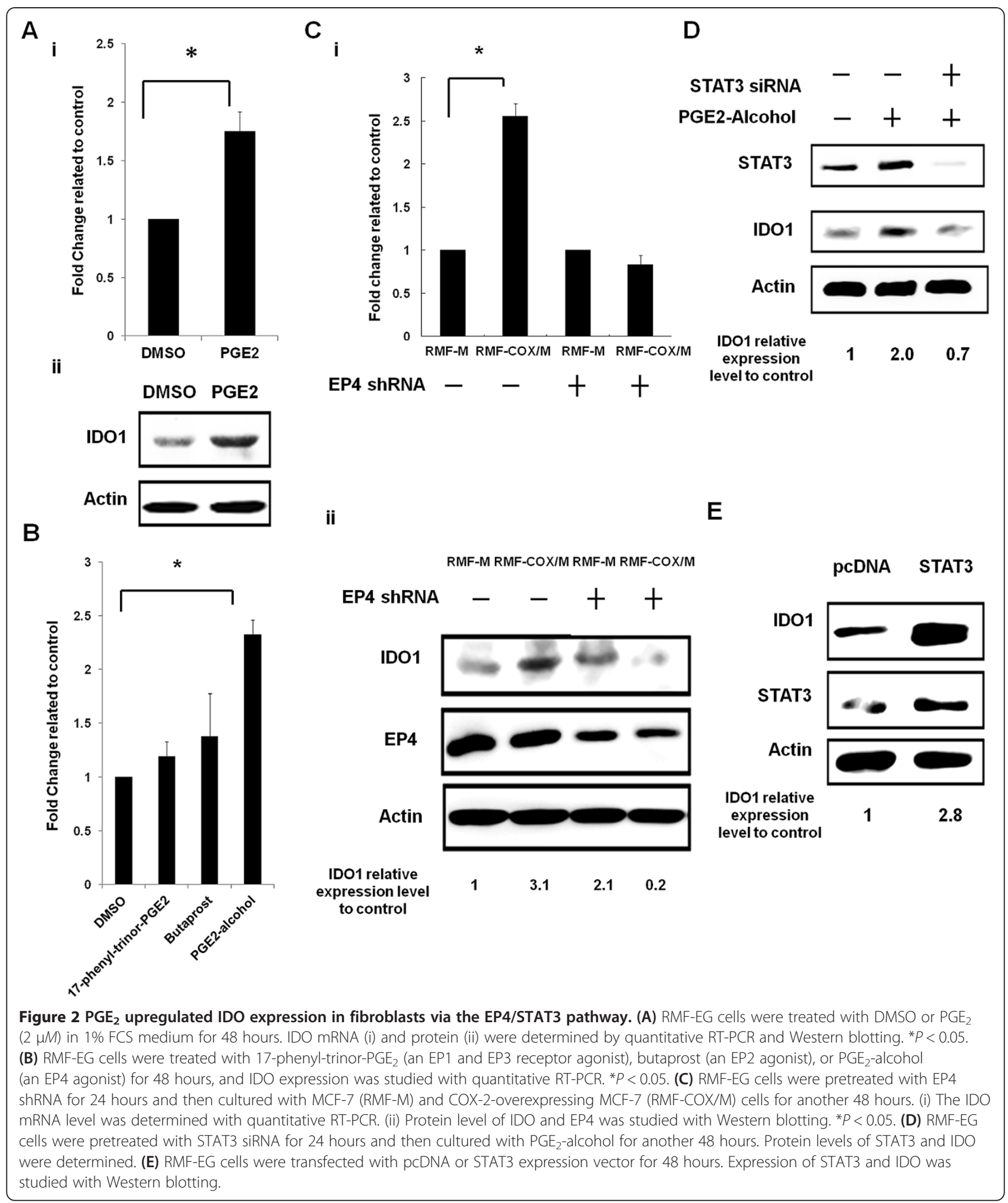

proteasome-dependent pathway, which could be rescued by MG132 (proteasome inhibitor) but not chloroquine (lysosome inhibitor) (Figure 3E). In addition, ubiquitination of E-cadherin protein was increased in kynurenine-treated MCF-7 cells (Figure 3F). These data suggest that kynurenine induces ubiquitination and degradation of E-cadherin to promote breast cancer cell motility. 


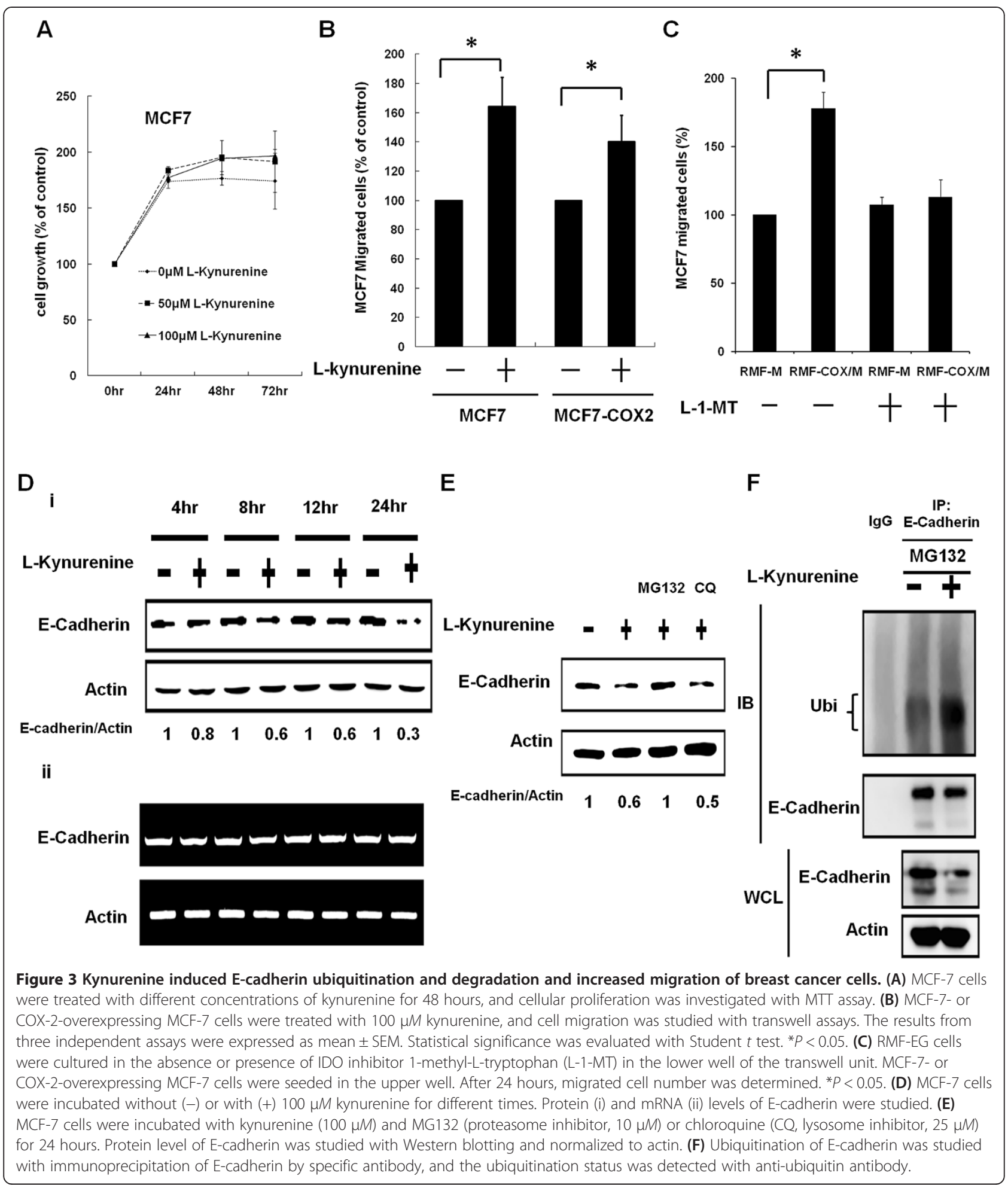

Kynurenine increased the degradation of E-cadherin in an AhR- and Skp2-dependent manner

Kynurenine has been shown to be an endogenous tumor-promoting ligand of the human AhR [25]. In addition, AhR is involved in the degradation of sex steroid receptors via a cullin $4 \mathrm{~B}$-dependent ubiquitination pathway [26]. We tested whether kynurenine reduced protein stability of E-cadherin through activation of $\mathrm{AhR}$ and found that the binding between AhR and E-cadherin was increased in 
kynurenine-treated MCF-7 cells (Figure 4A). Interestingly, Skp2, an F-box protein of the SCF E3 ligase, was co-immunoprecipitated with $\mathrm{AhR}$, and the interaction was also increased by kynurenine. We did not detect the cullin $4 \mathrm{~B}$ protein in the complex (data not shown). This is not a cell line-specific effect, because the interaction between $\mathrm{AhR}$ and E-cadherin protein was also elevated in kynurenine-treated A549 cells (see Additional file 4: Figure S3). The 3'-methylcholanthrene (3-MC), another AhR ligand, also induced co-localization of AhR and E-cadherin at the cell membrane (Figure 4B). Knockdown of Skp2 reversed kynurenine-induced reduction of E-cadherin protein without affecting AhR expression (Figure 4C). The AhR antagonist, 3'4'-dimethoxyflavone (3'4'-DMF), also inhibited the decrease of E-cadherin induced by

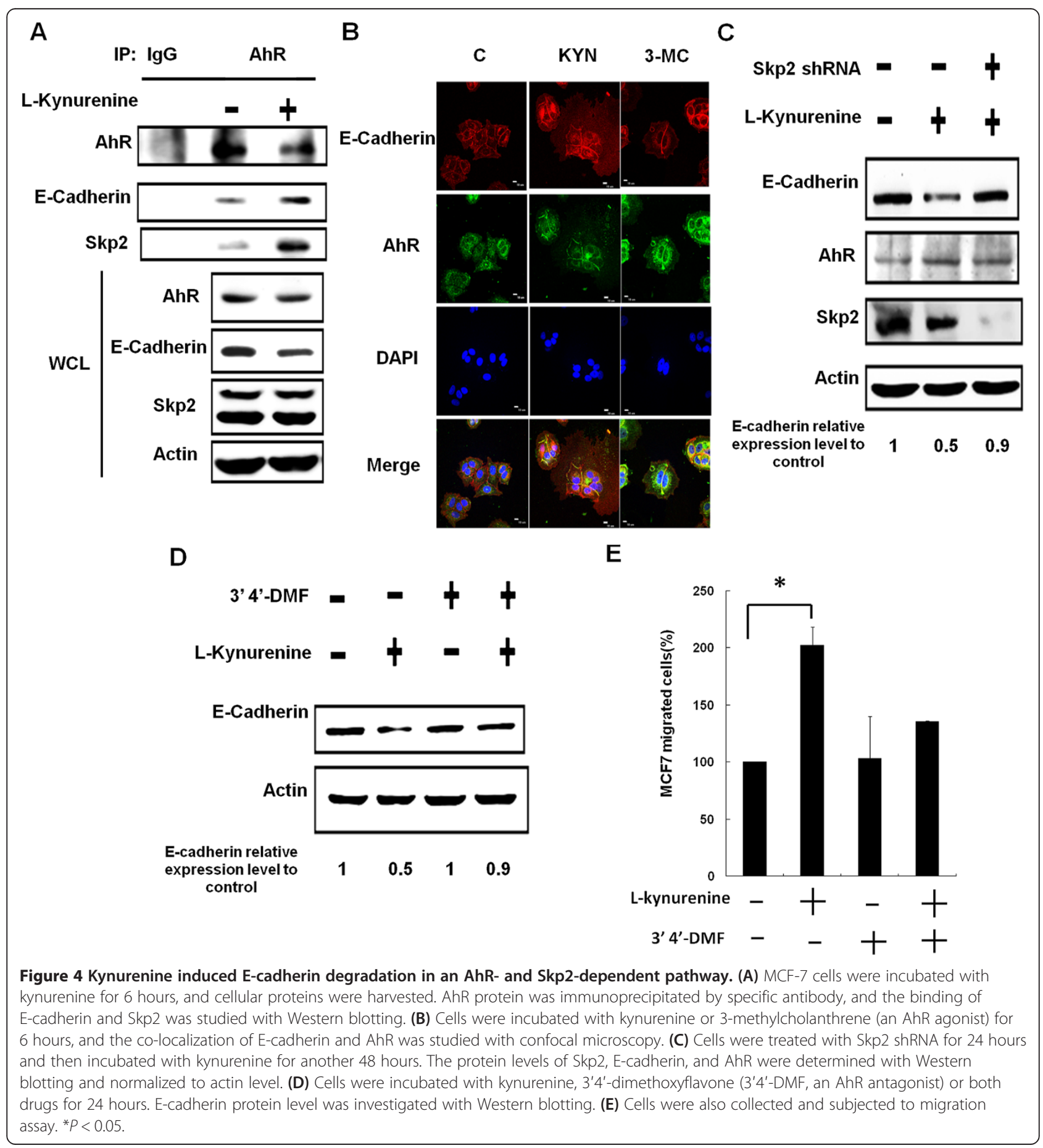


kynurenine (Figure 4D). Additionally, kynurenineincreased migration of MCF-7 cells was blocked by 3'4'-DMF (Figure 4E). These data suggest that kynurenine induces the formation of E-cadherin/AhR/Skp2 complex and causes E-cadherin degradation.

\section{COX-2 expression in breast cancer and IDO expression in stromal fibroblasts predicted poor disease-specific and metastasis-free survival}

The correlation between COX-2 expression in tumor tissues and IDO expression in CAFs was confirmed by two approaches. First, we isolated CAFs from two breast tumor tissues without or with COX-2 overexpression and found that IDO expression in CAFs was upregulated in COX-2overexpressing tumor (see Additional file 5: Figure S4). Second, we used immunohistochemical analysis to detect COX-2 and IDO expression in a cohort of breast cancer tissues (Figure 5A). COX-2 expression in tumors was positively correlated with a high IDO expression in CAFs (65 of 101, 64\%; $P<0.001$ ) (Table 1 ). COX-2 was highly expressed in stage III (19 of $24,79 \% ; P<0.05$ ), N1-N2 (61 of $85,71 \% ; P<0.001$ ), and T3-4 stage (20 of 24 , $83 \% ; P<0.05)$ tumor specimens. IDO expression in CAFs was significantly expressed in stage III (20 of 24, 83\%; $P<0.05$ ), N1-N2 (60 of 85, 71\%; $P<0.001$ ), and T3-4 stage (21 of $24,88 \% ; P<0.001$ ) tumor specimens. The disease-specific and metastasis-free survival declined significantly in patients with high COX-2 expression in breast tumors $(P=0.0043$ and $P<0.0001$, respectively) (Figure 5B and Table 2). Similarly, the disease-specific and metastasis-free survival declined significantly in patients with high IDO expression in CAFs $(P=0.0045$ and $P<0.0001$ ) (Figure $5 \mathrm{C}$ and Table 2). More important, high COX-2 in tumors and high IDO1 expression in CAFs predicted worse disease-free and metastasis-free survivals in breast cancer patients $(P<0.0001$, Figure 5D).

\section{COX-2 and IDO inhibitors suppressed growth of COX-2-overexpressing breast tumors in vivo}

The effect of COX-2 and IDO inhibitors was evaluated in an orthotopic model. Inoculation of MCF-7/RMF-EGor COX-2-overexpressing MCF-7/RMF-EG cell mixture induced tumors in nude mice primed with $17 \beta$-estradiol injection (Figure 6A). Tumor growth was higher in the COX-2-overexpressing MCF-7/RMF-EG group, and a 2.4-fold of increase of tumor volume was detected at 10 weeks $(P<0.01)$. The COX-2-overexpressing MCF-7/ RMF-EG group was randomly divided into four subgroups $(n=3)$. Intratumoral injection of vehicle (DMSO, control), $10 \mathrm{mg} / \mathrm{kg}$ of NS398, $10 \mathrm{mg} / \mathrm{kg}$ of 1-methyl-L-tryptophan, or both inhibitors was conducted, and treatment was continuous for another 2 weeks. As shown in Figure 6B, tumor volume of the groups treated with NS398 or 1-methyl-L-tryptophan was smaller than that of the control group. Co-treatment of COX-2 and IDO inhibitor induced a more obvious reduction in tumor size, although it did not show an additive effect.

\section{Discussion}

Previous studies demonstrated that IDO overexpression increases the secretion of kynurenine to inhibit effect $\mathrm{T}$ cells to promote immune escape and tumor progression in various human cancers [27-29]. The expression of IDO in cancer stroma has not been clarified. In addition, the clinical significance of stromal IDO is unclear.

In this study, we provide evidence that COX-2overexpressing breasts cancer cells may secrete $\mathrm{PGE}_{2}$ to induce IDO expression and kynurenine production in stromal fibroblasts. In addition, we show that kynurenine in the coculture-conditioned medium is produced mainly by CAFs because IDO is not induced by COX-2 overexpression in MCF-7 cells. An important upstream regulator of IDO is interferon- $\gamma$. Yoshida et al. [30] first reported that the pulmonary IDO was induced in the mouse after intraperitoneal administration of bacterial endotoxin or during in vivo virus infection, and this induction was triggered by interferon $-\gamma$ [30]. Because interferon- $\gamma$ exhibits antitumor activity on various cancers in vitro and in vivo, it is unlikely that COX-2overexpressing cancer cells produce interferon- $\gamma$ to stimulate stromal IDO. For the first time, we show that cancer cell-produced $\mathrm{PGE}_{2}$ transcriptionally upregulates IDO expression through the EP4/STAT3 signaling pathway. In vivo binding of STAT3 to IDO gene promoter is confirmed by ChIP assay. Additionally, knockdown of STAT3 totally abolishes EP4 agonist-induced IDO expression. These data suggest that IDO is a direct transcriptional target of STAT3.

An unresolved question is why $\mathrm{PGE}_{2}$ stimulates IDO expression in stromal fibroblasts but not in breast cancer cells, because both cell types express EP4 receptor [31 and data not shown]. We are aware that the binding of STAT1 to IDO promoter is reduced by $\mathrm{PGE}_{2}$ (Additional file 3: Figure S2); therefore, it is possible that the expression level of STAT1 and STAT3 and the competition between these two STATs may determine the response of cells to $\mathrm{PGE}_{2}$ stimulation.

The concept of oncometabolite was established by the studies that mutations of isocitrate dehydrogenase 1 (IDH1) and IDH2 generate a novel metabolite 2hydroxyglutarate (2-HG) that exhibits oncogenic activity in acute myeloid leukemia and glioma [32,33]. Subsequently, 2-HG was shown to be a competitive inhibitor of $\alpha$-ketoglutarate-dependent dioxygenases and inhibits histone demethylases like Tet methylcytosine dioxygenase 2 (TET2) to change promoter methylation and gene transcription [34,35]. Kynurenine represents another oncometabolite, which acts as an immunosuppressor to create 


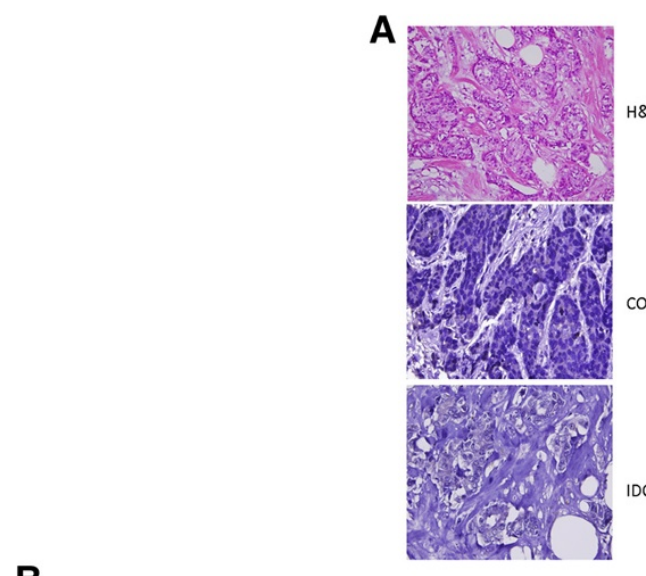

B
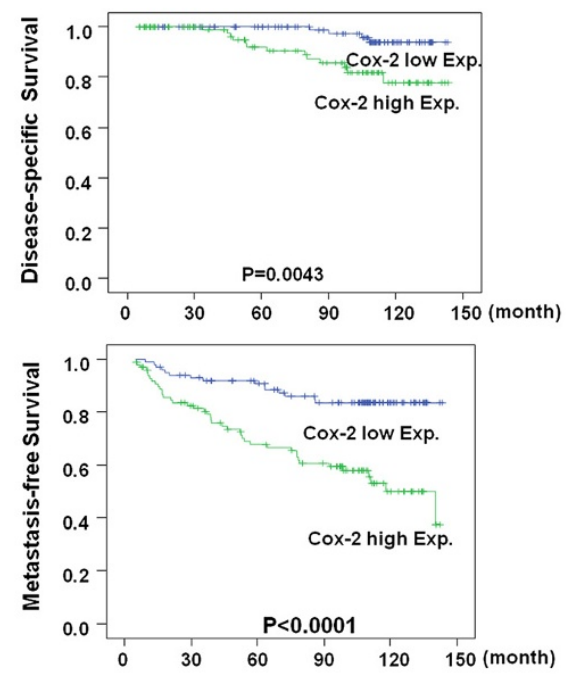

H\&E

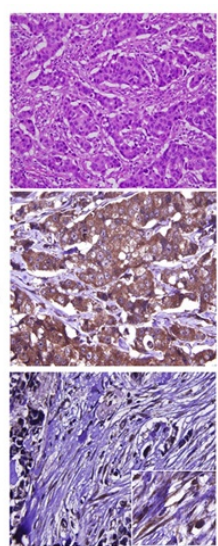

C
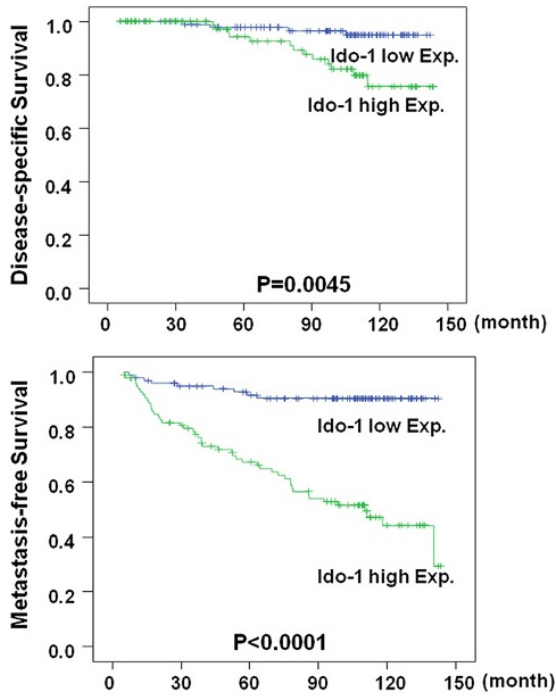

D
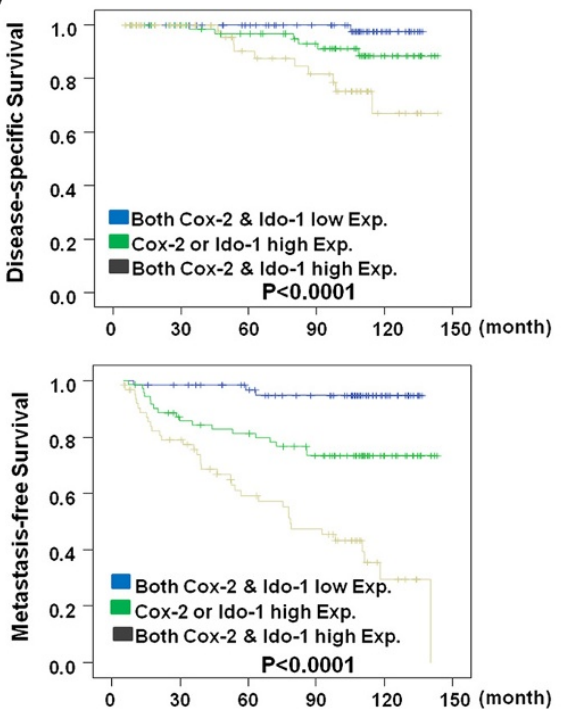

Figure 5 Coexpression of cancer COX-2 and stromal IDO predicted worse patient survival. (A) Immunohistochemical staining showed COX-2 expression in breast tumor tissues and IDO expression in tumor stroma. (B) High COX-2 expression in tumor tissues was associated with reduced disease-specific and metastasis-free survival. (C) High IDO expression in tumor stroma also was associated with reduced disease-specific and metastasis-free survival. (D) Coexpression of tumor COX-2 and stroma IDO predicted worse patient survival. 
Table 1 Correlation between Cox-2 and Ido-1 expression and various clinicopathologic factors

\begin{tabular}{|c|c|c|c|c|c|c|c|c|}
\hline \multirow[t]{2}{*}{ Parameters } & \multirow[t]{2}{*}{ Category } & \multirow{2}{*}{$\begin{array}{l}\text { No. of } \\
\text { cases }\end{array}$} & \multicolumn{2}{|c|}{ Cox-2 expression (tumor) } & \multirow[t]{2}{*}{$P$ value } & \multicolumn{2}{|c|}{ Ido-1 expression (CAF) } & \multirow[t]{2}{*}{$P$ value } \\
\hline & & & Low exp. & High exp. & & Low exp. & High exp. & \\
\hline \multirow[t]{2}{*}{ Age (years) } & $<60$ years & 141 & 73 & 68 & 0.444 & 69 & 72 & 0.647 \\
\hline & $\geqq 60$ years & 61 & 28 & 33 & & 32 & 29 & \\
\hline \multirow[t]{3}{*}{ Primary tumor $(\mathrm{T})$} & $\mathrm{T} 1$ & 82 & 45 & 37 & 0.002 & 44 & 38 & $<0.001$ \\
\hline & $\mathrm{T} 2$ & 96 & 52 & 44 & & 54 & 42 & \\
\hline & T3-4 & 24 & 4 & 20 & & 3 & 21 & \\
\hline \multirow[t]{2}{*}{ Nodal status (N) } & No & 117 & 77 & 40 & $<0.001$ & 76 & 41 & $<0.001$ \\
\hline & $\mathrm{N} 1-\mathrm{N} 2$ & 85 & 24 & 61 & & 25 & 60 & \\
\hline \multirow[t]{3}{*}{ Stage } & I & 63 & 37 & 26 & 0.006 & 37 & 26 & 0.002 \\
\hline & $\|$ & 115 & 59 & 56 & & 60 & 55 & \\
\hline & III & 24 & 5 & 19 & & 4 & 20 & \\
\hline \multirow[t]{3}{*}{ Histologic grade } & Grade I & 18 & 13 & 5 & 0.122 & 15 & 3 & 0.003 \\
\hline & Grade II & 141 & 69 & 72 & & 71 & 70 & \\
\hline & Grade III & 43 & 19 & 24 & & 15 & 28 & \\
\hline \multirow[t]{2}{*}{ CAF Ido-1 expression } & Low Exp. (<medium) & 101 & 65 & 35 & $<0.001$ & & & \\
\hline & High Exp. ( $\geqq$ medium) & 101 & 35 & 65 & & & & \\
\hline
\end{tabular}

Bold figures, Statistically significant.

a favorable microenvironment for tumor formation and metastasis [36]. A recent study demonstrated that the tryptophan catabolism enzyme TDO is overexpressed in human brain tumors, and elevated secretion of kynurenine promotes cell migration via an AhRdependent pathway [25].
However, the underlying mechanism by which kynurenine increases cell motility is still unclear. After screening of the EMT markers, we found that E-cadherin is decreased in kynurenine-treated breast cancer cells, and AhR is involved in this process. AhR has been shown to integrate as a component of a novel Cul4B ubiquitin

Table 2 Univariate log-rank analysis for disease-specific survival and metastasis-free survival

\begin{tabular}{|c|c|c|c|c|c|c|}
\hline \multirow[t]{2}{*}{ Parameters } & \multirow[t]{2}{*}{ Category } & \multirow[t]{2}{*}{ No. of case } & \multicolumn{2}{|l|}{ DSS } & \multicolumn{2}{|l|}{ MeFS } \\
\hline & & & No. of events & $P$ value & No. of events & $P$ value \\
\hline \multirow[t]{2}{*}{ Age (years) } & $<60$ years & 141 & 13 & 0.9804 & 41 & 0.7650 \\
\hline & $\geqq 60$ years & 61 & 4 & & 16 & \\
\hline \multirow[t]{3}{*}{ Primary tumor (T) } & $\mathrm{T} 1$ & 82 & 5 & 0.0283 & 9 & $<0.0001$ \\
\hline & $\mathrm{T} 2$ & 96 & 10 & & 34 & \\
\hline & T3-4 & 24 & 2 & & 14 & \\
\hline \multirow[t]{2}{*}{ Nodal status (N) } & No & 117 & 7 & 0.0079 & 19 & $<0.0001$ \\
\hline & $\mathrm{N} 1-2$ & 85 & 10 & & 38 & \\
\hline \multirow[t]{3}{*}{ Stage } & । & 63 & 3 & 0.0001 & 5 & $<0.0001$ \\
\hline & $\|$ & 115 & 10 & & 38 & \\
\hline & III & 24 & 4 & & 14 & \\
\hline \multirow[t]{3}{*}{ Histologic grade } & Grade I & 18 & 0 & 0.2066 & 1 & 0.0269 \\
\hline & Grade II & 141 & 15 & & 41 & \\
\hline & Grade III & 43 & 2 & & 15 & \\
\hline Cox-2 expression & Low Exp (<medium) & 101 & 4 & 0.0043 & 15 & $<0.0001$ \\
\hline (Tumor) & High Exp ( $\geqq$ medium) & 101 & 13 & & 42 & \\
\hline Ido-1 expression & Low Exp (<medium) & 101 & 4 & 0.0045 & 9 & $<0.0001$ \\
\hline (CAF) & High Exp (ミmedium) & 101 & 13 & & 48 & \\
\hline
\end{tabular}

Bold figures, Statistically significant. 

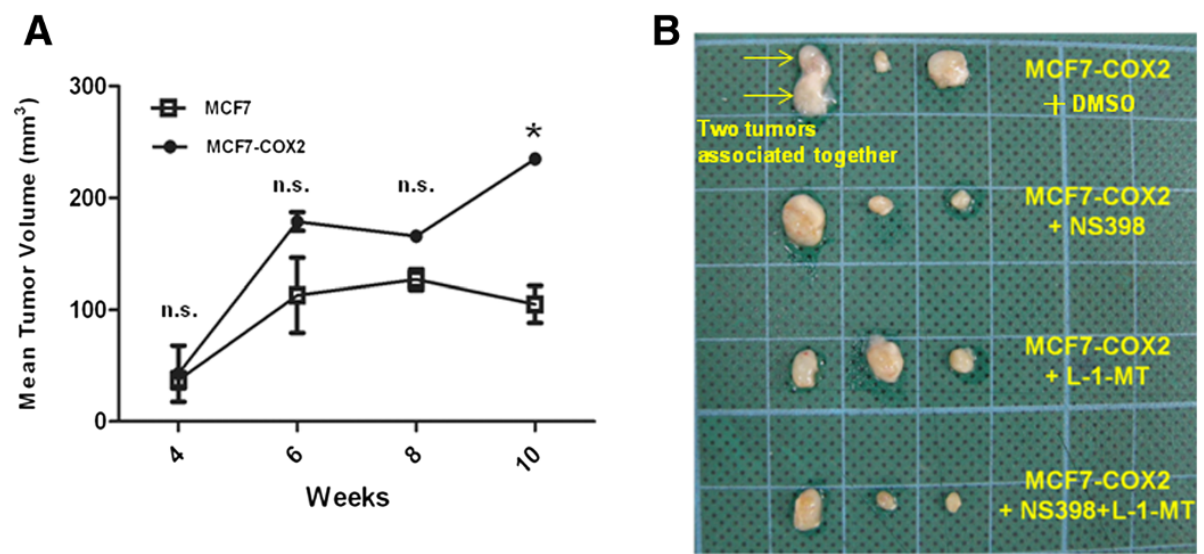

Figure 6 Inhibition of tumor growth by COX-2 and IDO inhibitors in vivo. (A) MCF-7 or MCF-7-COX2 $\left(8 \times 10^{6}\right)$ cells mixed with RMF-EG $\left(6 \times 10^{6}\right)$ cells were inoculated into the fourth mammary fat pads of 6 -week-old female nude mice. Before inoculation of the cancer cell/fibroblast mixture, all mice were primed with $6 \mathrm{mg} / \mathrm{kg}$ of $17 \beta$-estradiol twice a week for 3 weeks. Measurement of tumor growth was begun at 4 weeks after injection, and tumor volume was continuously monitored. The difference between the groups was evaluated by repeated measures two-way ANOVA analysis. n.S., no significance. ${ }^{*} P<0.01$. (B) After 10 weeks, mice injected with MCF-COX-2 and RMF-EG cells were randomly divided into four groups that received vehicle (DMSO), NS-398 (10 mg/kg), L-1-methy-tryptophan (10 mg/kg), or both inhibitors 5 times per week. Two weeks later, animals were killed, and tumors were isolated from mice.

E3 ligase complex and participated in the degradation of sex steroid receptors [26]. We demonstrated that kynurenine increases the interaction between AhR and E-cadherin, and the AhR/E-cadherin complex also contains Skp2, an F-box protein of SCF E3 ligase. The formation of the E-cadherin/AhR/Skp2 complex and ubiquitination of E-cadherin induced by kynurenine is also detectable in A549 cells, indicating a general mechanism of kynurenineinduced proteolysis of E-cadherin in different cancer cells. Our results provide a novel oncometabolite function of kynurenine to enhance cancer cell migration by degrading E-cadherin.

The clinical validation of tumor COX-2 and stromal IDO in this study is important to verify the cancerstroma interplay in cancer progression. Many histopathologic studies investigated the expression of two specific genes in the epithelial components of tumor tissues to show their association and to demonstrate the vertical regulation of these two genes. The correlation and clinical significance of genes separately expressed in tumor and stroma have received little attention.

However, the gene signatures in CAFs may provide more information than originally thought. West et al. [37] first classified two stromal gene signature from tumors with solitary fibrous tumor (SFT) and desmoids-type fibromatosis (DTF) features and showed that patients with the expression of DTF had a favorable clinical outcome. Their subsequent study by using public databases and immunohistochemical approaches suggested that DTF fibroblast signature is a common tumor stroma signature in different types of cancers [38]. Mercier et al. [39] identified a hyperproliferative gene signature in CAFs and found that breast cancer patients with this signature had a poor prognosis with tamoxifen monotherapy and a great reduction in recurrence-free survival [39]. By using a mouse model of squamous skin carcinogenesis, Erez [40] demonstrated that carcinoma cells could educate CAFs to express proinflammatory genes to promote macrophage recruitment, neovascularization, and tumor growth. Additionally, this gene signature was also evident in mammary and pancreatic tumors in mice and in human cancers. By using metabolomics, molecular, and pathological approaches, we revealed that induction of stromal IDO by COX-2-overexpressing breast cancer cells promotes tumor progression and predicts poor patient survival.

Results of our animal study also clearly demonstrate the anticancer effect of COX-2 and IDO inhibitor on COX-2-overexpressing breast cancer in vivo. A combination of IDO and COX-2 inhibitor exhibits a more obvious effect on the inhibition of tumor growth. However, we did not find an additive effect. This can be because (a) the number of animals in each group is small, and (b) inhibition of COX-2 in cancer cells will attenuate stromal IDO expression, which reduces the anticancer activity of IDO inhibitor. Additional experiments are needed to clarify this issue.

\section{Conclusion}

By using a metabolomics approach, we identified potential oncometabolites involved in the crosstalk between COX-2overexpressing breast cancer cells and fibroblasts. Molecular study elucidates the underlying mechanism by which this cancer/stroma interplay via COX-2 and IDO promotes tumor progression. In addition, pathological investigation 
validates the importance of cancer COX-2 and stromal IDO in the prediction of the patient's survival. Simultaneous targeting of COX-2 and IDO may be a new strategy for breast cancer treatment.

\section{Additional files}

\section{Additional file 1: Supplementary materials and methods.}

Additional file 2: Figure S1. $\mathrm{PGE}_{2}$ stimulated IDO promoter activity. Different IDO promoter constructs were transfected into MCF-7 cells and stimulated by $\mathrm{PGE}_{2}$. Promoter assay indicated that $\mathrm{PGE}_{2}$ activated $I D O$ via the $-1140 /-844$ promoter region.

Additional file 3: Figure S2. In vivo binding of STAT3 on IDO gene promoter in EMF-EG fibroblasts and its regulation by co-culture of COX-2-overexpressing MCF7 cells. ChIP assay demonstrated that the binding of STAT3 to IDO promoter was increased, whereas the binding of STAT1 was reduced in EMF-EG fibroblasts after co-culture with COX-2-overexpressing MCF-7 cells.

Additional file 4: Figure S3. Kynurenine induced the formation of E-cadherin/AhR/Skp2 complex in A549 lung cancer cells. A549 cells were treated without (-) or with (+) kynurenine, and the interaction between E-cadherin and AhR or Skp2 was studied by immunoprecipitation and Western blotting.

Additional file 5: Figure S4. IDO expression in cancer-associated fibroblasts (CAFs) was increased in COX-2-overexpressing breast cancer.

\section{Abbreviations}

2-HG: 2-hydroxyglutarate; 3'4'-DMF: 3'4'-dimethoxyflavone; 3-MC: 3'-methylcholanthrene; AhR: aryl hydrocarbon receptor; CAF: cancer-associated fibroblast; CXCL12: chemokine (C-X-C motif) ligand 12; CXCL14: chemokine (C-X-C motif) ligand 14; DAPI: 4',6-diamidino-2-phenylindole; DTF: desmoid-type fibromatosis; ELISA: enzyme-linked immunosorbent assay; EMT: epithelial-mesenchymal transition; EP4: prostaglandin E receptor 4; IDH: isocitrate dehydrogenase; IDO: indoleamine 2,3-dioxygenase; MMP: matrix metalloproteinase; NF-kB: nuclear factor kappa-light-chain-enhancer of activated B cells; $\mathrm{PGE}_{2}$ : prostaglandin $\mathrm{E}_{2}$; SDF-1: stromal cell-derived factor 1; SFT: solitary fibrous tumor; shRNA: short-hairpin RNA; Skp2: S-phase kinase-associated protein 2; STAT3: signal transducer and activator of transcription 3; TET2: Tet methylcytosine dioxygenase 2; UPLC: ultraperformance liquid chromatography.

\section{Competing interests}

The authors declare that they have no competing interests.

\section{Authors' contributions}

JY conducted cell culture, biochemical, and molecular biology assays and prepared the draft of the manuscript. CF did IHC study and pathological analysis and helped to draft the manuscript. CC performed metabolomics study and data analysis and helped to draft the manuscript. KK participated in the design of the study and helped to draft the manuscript. MF conceived of the study and participated in the preparation of primary cancer-associated fibroblasts. WC conceived of the study and participated in the design of the study and wrote the manuscript. All authors read and approved the final manuscript.

\section{Acknowledgements}

We deeply thank Dr. Wu KK for his continuous support and encouragement. We also thank Ms. Pei-Yung Nien for the isolation of primary CAFs and Dr. Delphine Allorge and Dr. Marion Soichot for providing human IDO promoter. This study was supported by grants from National Science Council (NSC 101-2321-B-400-003 and NSC 102-2321-B-400-003) and MOHW103-TD-B-111-05 from Excellence for Cancer Research Center Grant, the Ministry of Health and Welfare.

\section{Author details}

${ }^{1}$ National Institute of Cancer Research, National Health Research Institutes, No. 367, Shengli Road, Tainan 704, Taiwan. ${ }^{2}$ Department of Pathology, Chi-Mei Foundation Medical Center, Tainan 710, Taiwan. ${ }^{3}$ Institute of Cellular and System Medicine, National Health Research Institutes, Maoli 350, Taiwan. ${ }^{4}$ Department of Surgery, College of Medicine, Kaohsiung Medical University,
Kaohsiung 807, Taiwan. ${ }^{5}$ Department of Surgery, Kaohsiung Municipal Ta-Tung Hospital, Kaohsiung 807, Taiwan. ${ }^{6} \mathrm{Cancer}$ Center, Kaohsiung Medical University Hospital, Kaohsiung 807, Taiwan. ${ }^{7}$ Graduate Institute of Medicine, College of Medicine, Kaohsiung Medical University, Kaohsiung 807, Taiwan.

Received: 14 January 2014 Accepted: 10 July 2014 Published: 25 July 2014

\section{References}

1. Williams CS, Mann M, DuBois RN: The role of cyclooxygenases in inflammation, cancer, and development. Oncogene 1999, 18:7908-7916.

2. Terzic J, Grivennikov S, Karin E, Karin M: Inflammation and colon cancer. Gastroenterology 2010, 138:2101-2114. e2105.

3. Howe LR: Inflammation and breast cancer: cyclooxygenase/prostaglandin signaling and breast cancer. Breast Cancer Res 2007, 9:210.

4. Ristimaki A, Sivula A, Lundin J, Lundin M, Salminen T, Haglund C, Joensuu H, Isola J: Prognostic significance of elevated cyclooxygenase-2 expression in breast cancer. Cancer Res 2002, 62:632-635.

5. Wulfing P, Diallo R, Muller C, Wulfing C, Poremba C, Heinecke A, Rody A, Greb RR, Bocker W, Kiesel L: Analysis of cyclooxygenase-2 expression in human breast cancer: high throughput tissue microarray analysis. J Cancer Res Clin Oncol 2003, 129:375-382.

6. Davies G, Salter J, Hills M, Martin LA, Sacks N, Dowsett M: Correlation between cyclooxygenase-2 expression and angiogenesis in human breast cancer. Clin Cancer Res 2003, 9:2651-2656.

7. Egan KM, Stampfer MJ, Giovannucci E, Rosner BA, Colditz GA: Prospective study of regular aspirin use and the risk of breast cancer. J Nat/ Cancer Inst 1996, 88:988-993.

8. Arun B, Goss P: The role of COX-2 inhibition in breast cancer treatment and prevention. Semin Oncol 2004, 31:22-29.

9. Chang SH, Liu CH, Conway R, Han DK, Nithipatikom K, Trifan OC, Lane TF, Hla T: Role of prostaglandin E2-dependent angiogenic switch in cyclooxygenase 2-induced breast cancer progression. Proc Natl Acad Sci US A 2004, 101:591-596.

10. Howe LR, Subbaramaiah K, Patel J, Masferrer JL, Deora A, Hudis C, Thaler HT, Muller WJ, Du B, Brown AM, Dannenberg AJ: Celecoxib, a selective cyclooxygenase 2 inhibitor, protects against human epidermal growth factor receptor 2 (HER-2)/neu-induced breast cancer. Cancer Res 2002, 62:5405-5407.

11. Harris RE, Alshafie GA, Abou-lssa H, Seibert K: Chemoprevention of breast cancer in rats by celecoxib, a cyclooxygenase 2 inhibitor. Cancer Res 2000, 60:2101-2103.

12. Aboussekhra A: Role of cancer-associated fibroblasts in breast cancer development and prognosis. Int J Dev Biol 2011, 55:841-849.

13. Orimo A, Gupta PB, Sgroi DC, Arenzana-Seisdedos F, Delaunay T, Naeem R, Carey VJ, Richardson AL, Weinberg RA: Stromal fibroblasts present in invasive human breast carcinomas promote tumor growth and angiogenesis through elevated SDF-1/CXCL12 secretion. Cell 2005, 121:335-348.

14. Allinen M, Beroukhim R, Cai L, Brennan C, Lahti-Domenici J, Huang H, Porter D, Hu M, Chin L, Richardson A, Schnitt S, Sellers WR, Polyak K: Molecular characterization of the tumor microenvironment in breast cancer. Cancer Cell 2004, 6:17-32.

15. Hu M, Peluffo G, Chen H, Gelman R, Schnitt S, Polyak K: Role of COX-2 in epithelial-stromal cell interactions and progression of ductal carcinoma in situ of the breast. Proc Natl Acad Sci U S A 2009, 106:3372-3377.

16. Kuperwasser C, Chavarria T, Wu M, Magrane G, Gray JW, Carey L, Richardson A, Weinberg RA: Reconstruction of functionally normal and malignant human breast tissues in mice. Proc Natl Acad Sci U S A 2004, 101:4966-4971.

17. Cheng HH, Kuo CC, Yan JL, Chen HL, Lin WC, Wang KH, Tsai KK, Guvén H, Flaberg E, Szekely L, Klein G, Wu KK: Control of cyclooxygenase-2 expression and tumorigenesis by endogenous 5-methoxytryptophan. Proc Natl Acad Sci U S A 2012, 109:13231-13236.

18. Wishart DS, Knox C, Guo AC, Eisner R, Young N, Gautam B, Hau DD, Psychogios N, Dong E, Bouatra S, Mandal R, Sinelnikov I, Xia J, Jia L, Cruz JA, Lim E, Sobsey CA, Shrivastava S, Huang P, Liu P, Fang L, Peng J, Fradette R, Cheng D, Tzur D, Clements M, Lewis A, De Souza A, Zuniga A, Dawe M, et al: HMDB: a knowledge base for the human metabolome. Nucleic Acid Res 2009, 37:D603-610.

19. Chan CH, Li CF, Yang WL, Gao Y, Lee SW, Feng Z, Huang HY, Tsai KK, Flores LG, Shao Y, Hazle JD, Yu D, Wei W, Sarbassov D, Hung MC, Nakayama KI, Lin 
HK: The Skp2-SCF E3 ligase regulates Akt ubiquitination, glycolysis, herceptin sensitivity, and tumorigenesis. Cell 2012, 149:1098-1111.

20. Horai H, Arita M, Kanaya S, Nihei Y, Ikeda T, Suwa K, Ojima Y, Tanaka K, Tanaka S, Aoshima K, Oda Y, Kakazu Y, Kusano M, Tohge T, Matsuda F, Sawada Y, Hirai MY, Nakanishi H, Ikeda K, Akimoto N, Maoka T, Takahashi H, Ara T, Sakurai N, Suzuki H, Shibata D, Neumann S, lida T, Tanaka K, Funatsu $\mathrm{K}$, et al: MassBank: a public repository for sharing mass spectral data for life sciences. J Mass Spectrom 2010, 45:703-714.

21. Soichot M, Hennart B, Al Saabi A, Leloire A, Froguel P, Levy-Marchal C, Poulain-Godefroy O, Allorge D: Identification of a variable number of tandem repeats polymorphism and characterization of LEF-1 response elements in the promoter of the IDO1 gene. PLoS One 2011, 6:e25470.

22. Decker T, Kovarik P, Meinke A: GAS elements: a few nucleotides with a major impact on cytokine-induced gene expression. $J$ Interferon Cytokine Res 1997, 17:121-134.

23. Du MX, Sotero-Esteva WD, Taylor MW: Analysis of transcription factors regulating induction of indoleamine 2,3-dioxygenase by IFN-gamma. $J$ Interferon Cytokine Res 2000, 20:133-142.

24. Sumpter TL, Dangi A, Matta BM, Huang C, Stolz DB, Vodovotz Y, Thomson AW, Gandhi CR: Hepatic stellate cells undermine the allostimulatory function of liver myeloid dendritic cells via STAT3-dependent induction of IDO. J Immunol 2012, 189:3848-3858.

25. Opitz CA, Litzenburger UM, Sahm F, Ott M, Tritschler I, Trump S, Schumacher T, Jestaedt L, Schrenk D, Weller M, Jugold M, Guillemin GJ, Miller CL, Lutz C, Radlwimmer B, Lehmann I, von Deimling A, Wick W, Platten M: An endogenous tumour-promoting ligand of the human aryl hydrocarbon receptor. Nature 2011, 478:197-203.

26. Ohtake F, Baba A, Takada I, Okada M, Iwasaki K, Miki H, Takahashi S, Kouzmenko A, Nohara K, Chiba T, Fujii-Kuriyama Y, Kato S: Dioxin receptor is a ligand-dependent E3 ubiquitin ligase. Nature 2007, 446:562-566.

27. Mansfield AS, Heikkila PS, Vaara AT, von Smitten KA, Vakkila JM, Leidenius MH: Simultaneous Foxp3 and IDO expression is associated with sentinel lymph node metastases in breast cancer. BMC Cancer 2009, 9:231.

28. Frumento G, Rotondo R, Tonetti M, Damonte G, Benatti U, Ferrara GB: Tryptophan-derived catabolites are responsible for inhibition of $\mathrm{T}$ and natural killer cell proliferation induced by indoleamine 2, 3-dioxygenase. J Exp Med 2002, 196:459-468.

29. Muller AJ, DuHadaway JB, Donover PS, Sutanto-Ward E, Prendergast GC: Inhibition of indoleamine 2, 3-dioxygenase, an immunoregulatory target of the cancer suppression gene Bin1, potentiates cancer chemotherapy. Nat Med 2005, 11:312-319.

30. Yasui $H$, Takai $K$, Yoshida R, Hayaishi O: Interferon enhances tryptophan metabolism by inducing pulmonary indoleamine 2,3-dioxygenase: its possible occurrence in cancer patients. Proc Natl Acad Sci U S A 1986, 83:6622-6626

31. Pan MR, Hou MF, Chang HC, Hung WC: Cyclooxygenase-2 up-regulates CCR7 via EP2/EP4 receptor signaling pathways to enhance lymphatic invasion of breast cancer cells. J Biol Chem 2008, 283:11155-11163.

32. Gross S, Cairns RA, Minden MD, Driggers EM, Bittinger MA, Jang HG, Sasaki M, Jin S, Schenkein DP, Su SM, Dang L, Fantin VR, Mak TW: Cancer-associated metabolite 2-hydroxyglutarate accumulates in acute myelogenous leukemia with isocitrate dehydrogenase 1 and 2 mutations. J Exp Med 2010, 207:339-344.

33. Ward PS, Patel J, Wise DR, Abdel-Wahab O, Bennett BD, Coller HA, Cross JR, Fantin VR, Hedvat CV, Perl AE, Rabinowitz JD, Carroll M, Su SM, Sharp KA, Levine RL, Thompson CB: The common feature of leukemia-associated IDH1 and IDH2 mutations is a neomorphic enzyme activity converting alpha-ketoglutarate to 2-hydroxyglutarate. Cancer Cell 2010, 17:225-234.

34. Figueroa ME, Abdel-Wahab O, Lu C, Ward PS, Patel J, Shih A, Li Y, Bhagwat N, Vasanthakumar A, Fernandez HF, Tallman MS, Sun Z, Wolniak K, Peeters JK, Liu W, Choe SE, Fantin VR, Paietta E, Lowenberg B, Licht JD, Godley LA, Delwel R, Valk PJ, Thompson CB, Levine RL, Melnick A: Leukemic IDH1 and IDH2 mutations result in a hypermethylation phenotype, disrupt TET2 function, and impair hematopoietic differentiation. Cancer Cell 2010, 18:553-567.

35. Xu W, Yang $H$, Liu Y, Yang Y, Wang $P$, Kim SH, Ito S, Yang C, Wang P, Xiao MT, Liu LX, Jiang WQ, Liu J, Zhang JY, Wang B, Frye S, Zhang Y, Xu YH, Lei QY, Guan KL, Zhao SM, Xiong Y: Oncometabolite 2-hydroxyglutarate is a competitive inhibitor of alpha-ketoglutarate-dependent dioxygenases. Cancer Cell 2011, 19:17-30.
36. Platten M, Wick W, Van den Eynde BJ: Tryptophan catabolism in cancer: beyond IDO and tryptophan depletion. Cancer Res 2012, 72:5435-5440.

37. West RB, Nuyten DS, Subramanian $S$, Nielsen TO, Corless CL, Rubin BP, Montgomery K, Zhu S, Patel R, Hernandez-Boussard T, Goldblum JR, Brown $\mathrm{PO}$, van de Vijver M, van de Rijn M: Determination of stromal signatures in breast carcinoma. PLOS Biol 2005, 3:e187.

38. Chen JL, Espinosa I, Lin AY, Liao OY, van de Rijn M, West RB: Stromal responses among common carcinomas correlated with clinicopathologic features. Clin Cancer Res 2013, 19:5127-5135.

39. Mercier I, Casimiro MC, Wang C, Rosenberg AL, Quong J, Minkeu A, Allen KG, Danilo C, Sotgia F, Bonuccelli G, Jasmin JF, Xu H, Bosco E, Aronow B, Witkiewicz A, Pestell RG, Knudsen ES, Lisanti MP: Human breast cancer-associated fibroblasts (CAFs) show caveolin-1 downregulation and RB tumor suppressor functional inactivation: implications for the response to hormonal therapy. Cancer Biol Ther 2008, 7:1212-1225.

40. Erez N, Truitt M, Olson P, Arron ST, Hanahan D: Cancer-associated fibroblasts are activated in incipient neoplasia to orchestrate tumor-promoting inflammation in an NF-kappaB-dependent manner. Cancer Cell 2010, 17:135-147.

doi:10.1186/s13058-014-0410-1

Cite this article as: Chen et al: Cancer/stroma interplay via cyclooxygenase-2 and indoleamine 2,3-dioxygenase promotes breast cancer progression. Breast Cancer Research 2014 16:410.

\section{Submit your next manuscript to BioMed Central and take full advantage of:}

- Convenient online submission

- Thorough peer review

- No space constraints or color figure charges

- Immediate publication on acceptance

- Inclusion in PubMed, CAS, Scopus and Google Scholar

- Research which is freely available for redistribution 